Iranian Journal of Breast Diseases. 2020; 13(2):59-68.

\section{Original Article \\ The Effect of Endurance Training Along with Curcumin on VEGF-A Level and VEGFR Gene Expression in Cancer Tissue of Female Mice with Breast Cancer}

\author{
Kouchaki Langroudi $F^{1}$, Peeri $\mathbf{M}^{1^{*}}$, Azarbayjani $M \mathbf{A}^{1}$, Delfan $\mathbf{M}^{2}$ \\ ${ }^{1}$ Department of Exercise Physiology, Central Tehran branch, Islamic Azad \\ University, Tehran, Iran \\ ${ }^{2}$ Department of Exercise Physiology, Faculty of Sport Sciences, Alzahra \\ University, Tehran, Iran
}

Receive: 6/1/2020

Accepted: 11/2/2020

"Corresponding Author: m.peeri@iauctb.ac.ir

Ethics Approval: IR.SSRI.REC. 1398.620

\begin{abstract}
Introduction: Breast cancer is the most common cancer and leading cause of death among women worldwide. The aim of the present study was to determine synergistic effects of 5 weeks of endurance training along with curcumin on cancer progression, levels of VEGF-A, and gene expression of VEGFR in cancer tissue of female Mice with breast cancer.
\end{abstract}

Methods: The present study was an experimental study. Forty female $\mathrm{BALB} / \mathrm{c}$ mice were transplanted with $4 \mathrm{~T} 1$ tumors and randomly divided into four groups including an endurance training group (E) (5 weeks, five days a week), a curcumin group (CC), an endurance training along with curcumin (E-C), and a control group (C). All animals were killed 24 hours following the last training session, and tumors were immediately extracted. Levels of VEGF-A and gene expression of VEGFR were determined by a western blot and quantitative real-time PCR, respectively. Data were analyzed with a one-way analysis of variance. The level of significance was set at 0.05 .

Results: The results of the present study showed a significant decrease in cancer progression $(\mathrm{p}<0.001)$, tumor levels of VEGFA $(\mathrm{p}<0.001)$, and $V E G F R$ expression $(\mathrm{p}<0.001)$ in the $\mathrm{E}, \mathrm{CC}$, and - especially-E-C groups compared with the control group.

Conclusion: It seems that 5 weeks of endurance training in combination with curcumin supplementation may have greater inhibitory effect on angiogenesis mechanisms, including VEGF-A/VEFR axis, resulting in greater decrease in cancer progression in mice with breast cancer in comparison with $\mathrm{E}$ and $\mathrm{CC}$ groups.

Keywords: Endurance Training, Curcumin, Breast Cancer, VEGF-A, VEGFR, Angiogenesis 


\author{
فرامرز كوجكى لنغرودى'، مقصود يِيرى "،. محمد على آذربايجانى'، مريم دلفان' \\ ' كروه فيزيولوزى ورزشى، واحد تهران مركزى، دانشعاه آزاد اسلامى، تهران، ايران

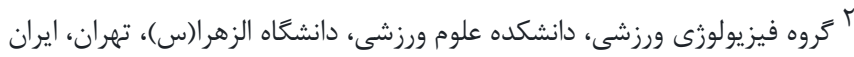

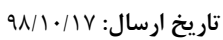

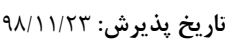

مقدمه: سرطان يستان شايعترين و مهممترين عامل مرگى و مير زنان در سراسر دنيا به شمار مىرود.

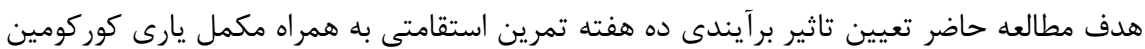

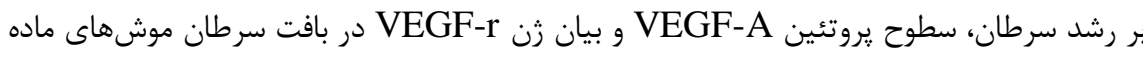

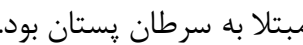

روش بررسى: يزوهش حاضر از نوع تجربى بود. · f سر موش ماده آزمايشعاهى نزاد بالب سى يس از

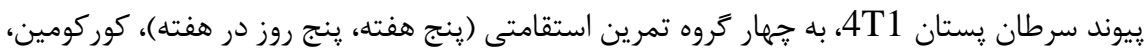

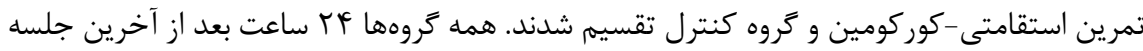

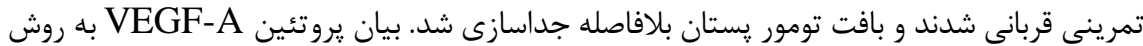

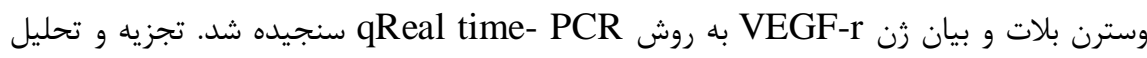

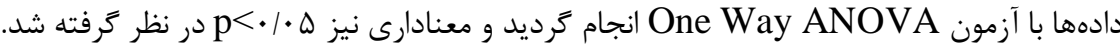

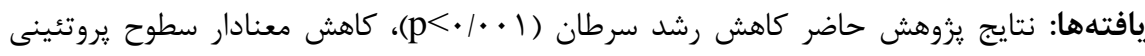
VEGF-A

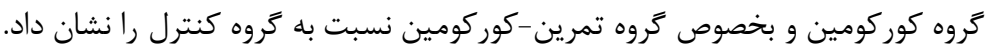
نتيجهَيرى: به نظر مىرسد ه هفته تمرين استقامتى همراه با مكمل يارى كوركومين احتمالا با

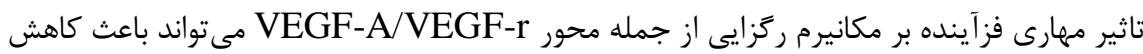

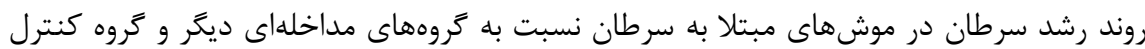
شود. وازمهاى كليدى: تمرين استقامتى، كوركومين، سرطان يستان، VEGF-r ،VEGF-A، رززايى

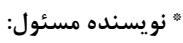

m.peeri@iauctb.ac.ir 
يروتئينى VEGF-A منجر به مهار ركزايى در بافت

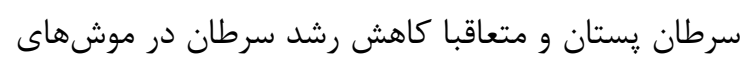

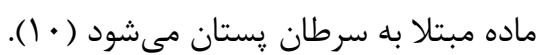

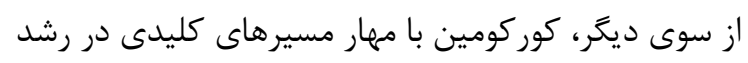

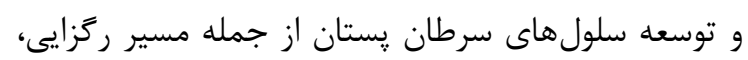
به عنوان يك عامل ضدسرطانى قوى به شمار مى برود (11). به نحوى كه نشان داده شده كه كوركومين با كاهش بـ بيان

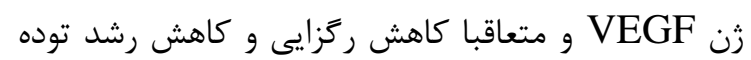
سرطانى در بافت سرطان گُشتان

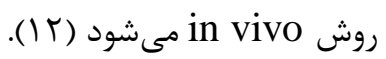
اينكه تمرين ورزشى در تركيب با كوركومين بر مسيرهاى

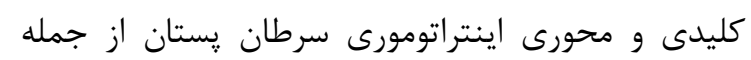

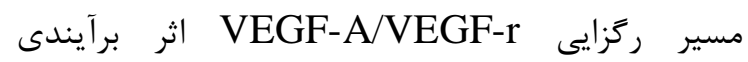
مى كذارد، هنوز هم يك مطالعه انجام نكرفته است. اين خود

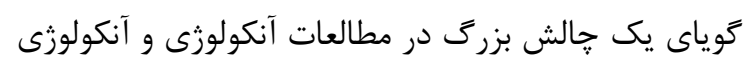

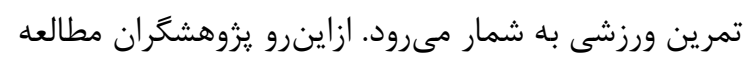

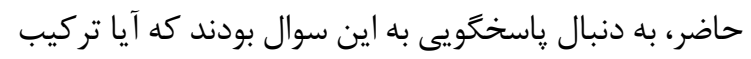

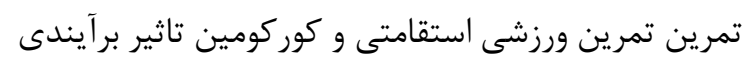

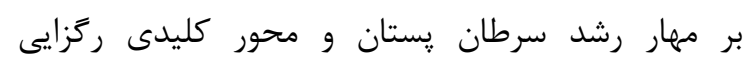
VEGF-A/VEGF-r

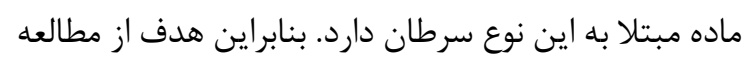
حاضر تعيين اثر برآيندى تمرين استقامتى به همراه مكمل يارى كور كومين بر محور ركزايى مذكور بود.

\section{مواد و روشها}

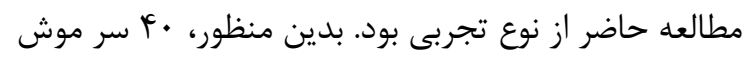

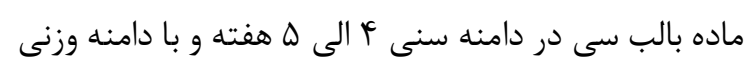

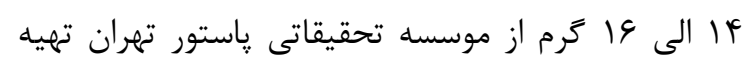

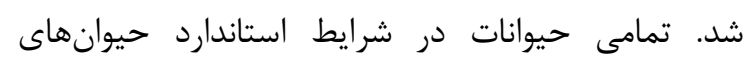

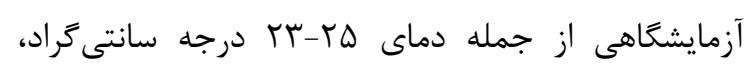

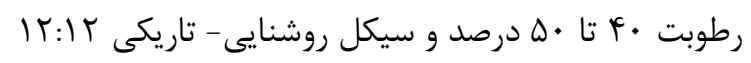

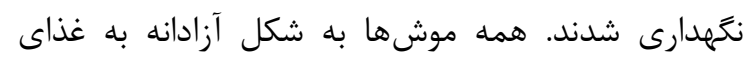

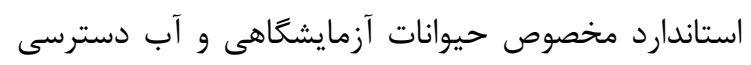

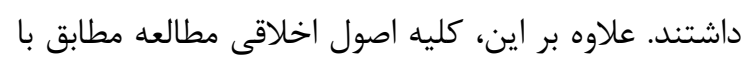

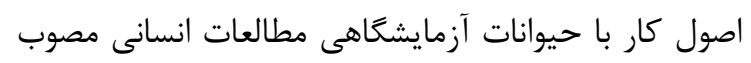

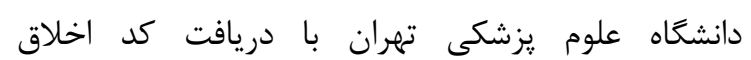
(IR.SSRI.REC.1398.620) ورزشى در طول دوره يزوهش توسط يزوهشكران رعايت كرديد. شايعترين نوع سرطان در ميان زنان در سراسر دنيا سرطان

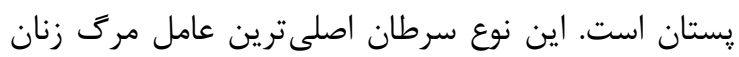

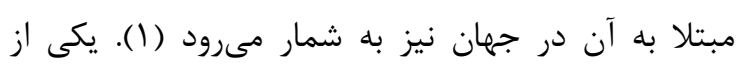

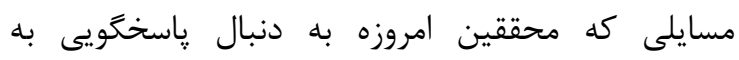
آن هستند اين است كه جكَونه مىتوانند مسيرهاى

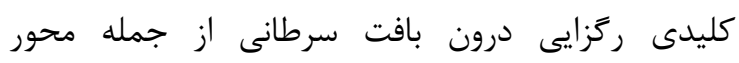

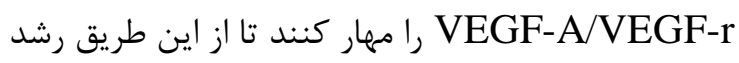

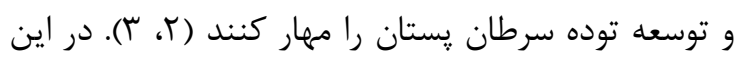

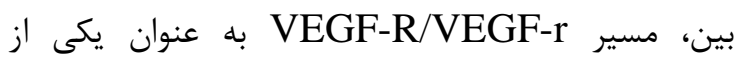

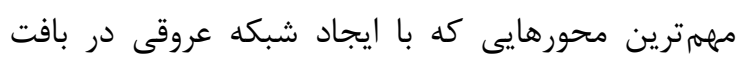

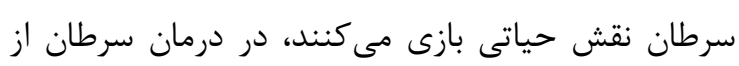

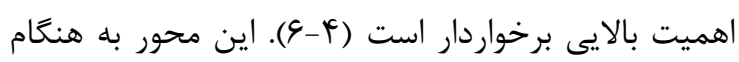

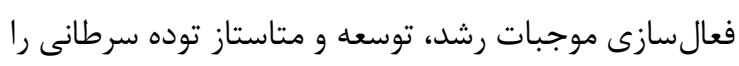

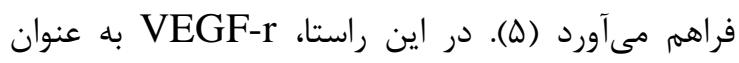

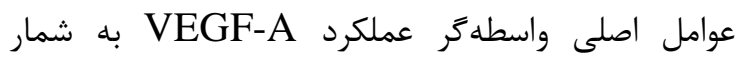
مىروند. VEGF توسط محركهاى مختلفى از جمله فاكتورهاى مختلف رشد، سايتوكاينها، هورمونها، اختلال

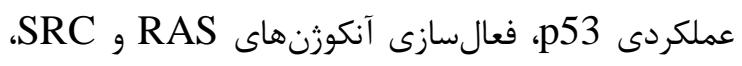
HER2

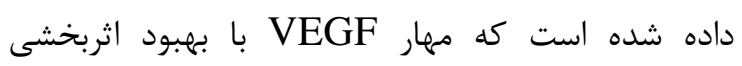

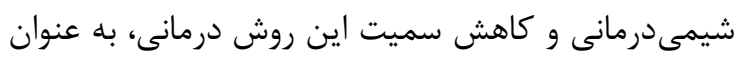

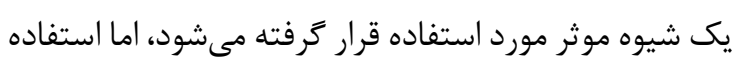
از اين روش نيز در طولانى مدت عواقب خطرناكى به دنبال

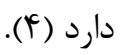
از مسايل ديخرى كه امروزه يزوهشكَران بروى آن تمركز

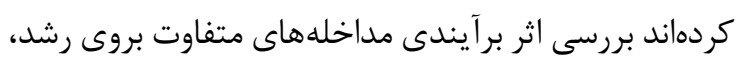

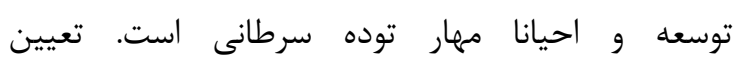
نقش زيربنايى و ساختارى تمرين ورزشى در تركيب باريان

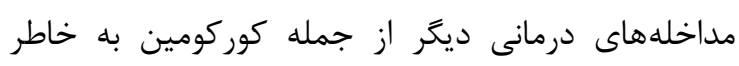

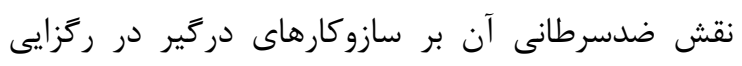

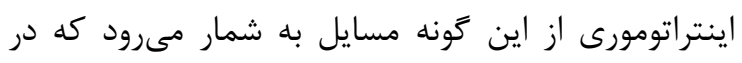

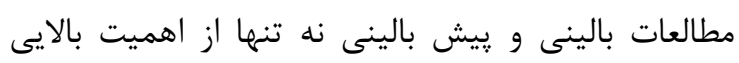

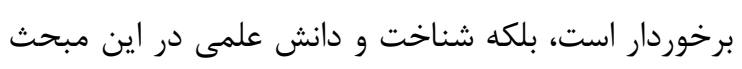

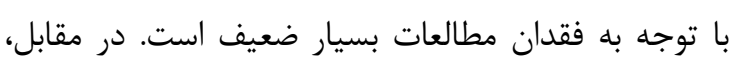

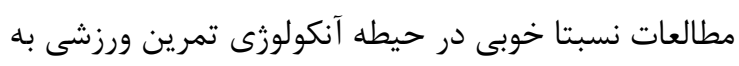

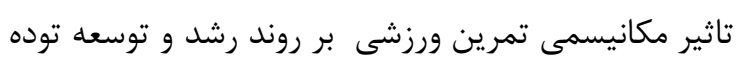

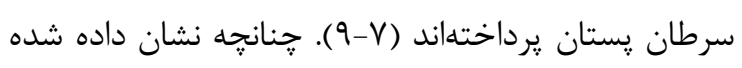
است كه تمرين استقامتى از طريق كاهش بيان سطوح 
علاوه بر اين، در طول مطالعه موشهاى كروه C و كروه E

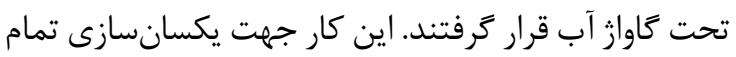

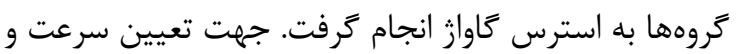
شدت يروتكل از روشى كه دلفان و همكارانش در سال

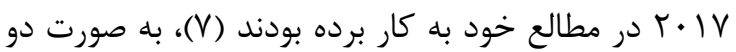
هفته يك بار استفاده كرديد.

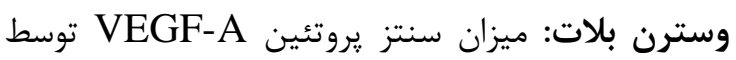
روش وسترن بلات اندازمخيرى شد. يس پان از تعيين مقادير مساوى از يروتئين عامل مذكور توسط تكنيك الكتروفورز،

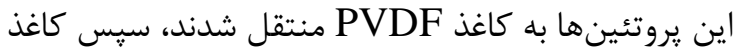

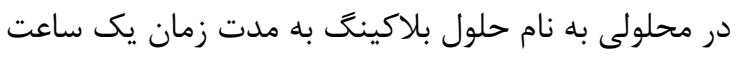

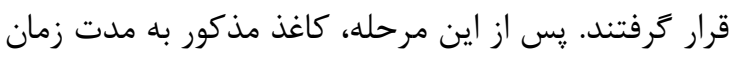
يك شب در محيطى به همراه آنتى بادى اوليه (ساخت

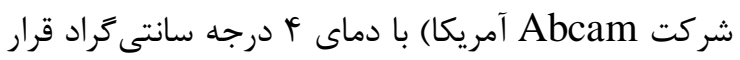

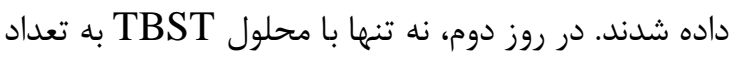
r مرتبه شستشو داده شدند، بلكه با استفاده از آنتىبادى دادي ثانويه اين كاغذ به مدت يك ساعت انكوبه شد. بعد از اينكه إندا

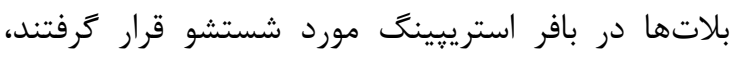

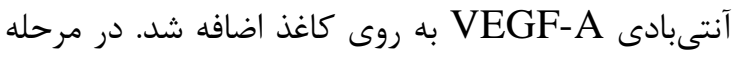
بعد كاغذ با آنتىبادى ثانويه انكوبه شد. در نهايت جهت

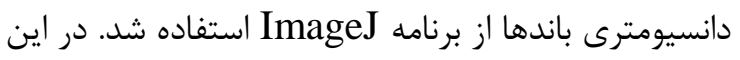
تكنيك از يروتئين خانهدارى GAPDH براى كندامه كنترل داخلى استفاده شد. qReal-Time PCR

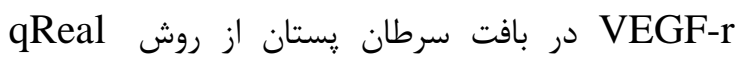
Real Time PCR استفاده كرديد. برنامه The PCR با دستگاه "Rotrogene 6000, Corbet" ساخت كشور

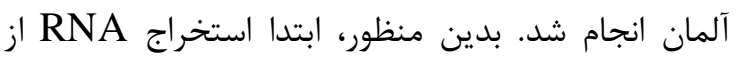

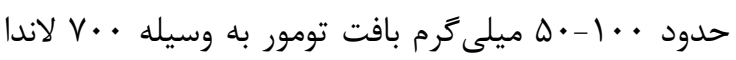
ترايزول استخراج شد. قبل از سنتز cDNA براى اطمينان

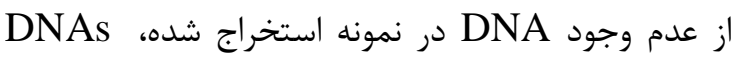
سن Thermo scientific) treatment سنتز cDNA با كيت Transcriptor first strand دoche) cDNA synthesis kit دستور العمل كيت صورت گرفت. سيس cDNA سنتز شده

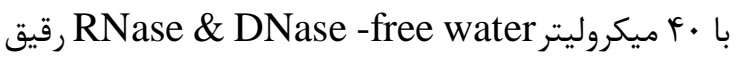

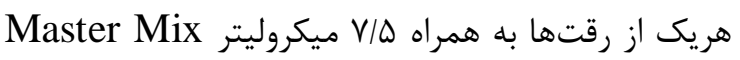

نحوه ايجاد سرطان پِّتان در موشها: ابتدا تمامى

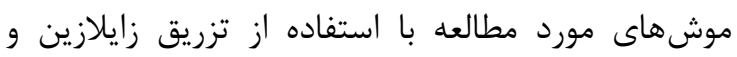

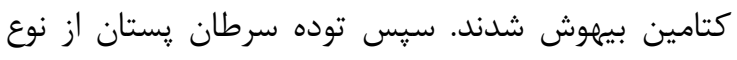

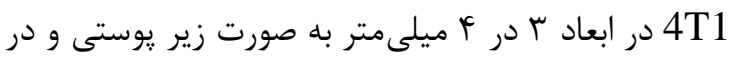

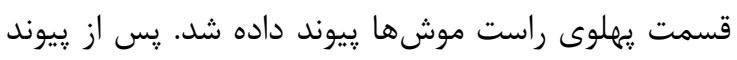

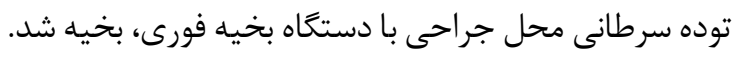

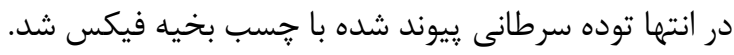

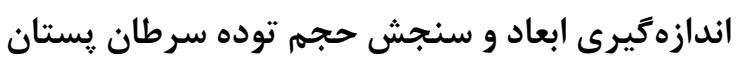

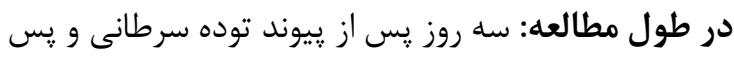

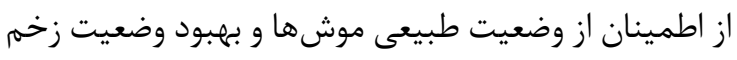
در محل ييوند، حجم توده سرطانى با استفاده از كوليس

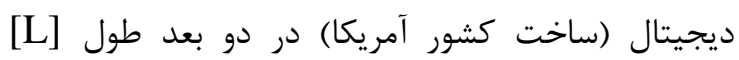

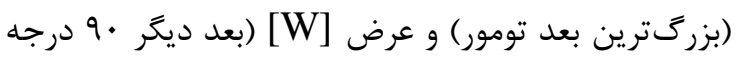

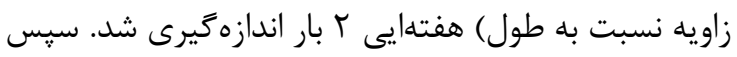
براى سنجش حجم توده از فرمول ]

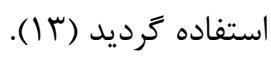

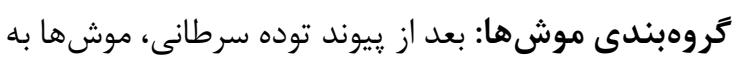

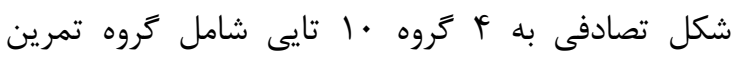

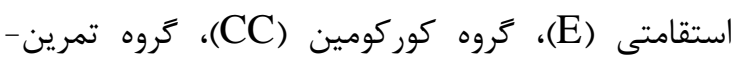

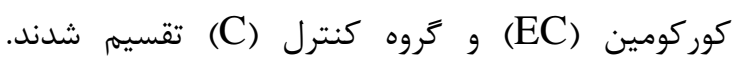

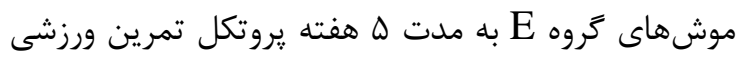

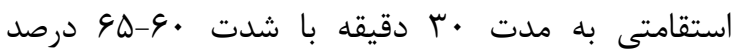
(velocity at maximal oxygen uptake)

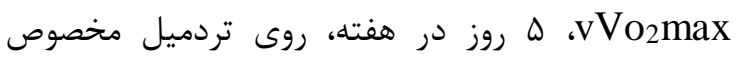

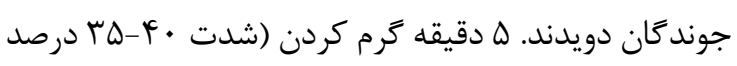

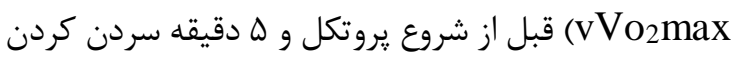

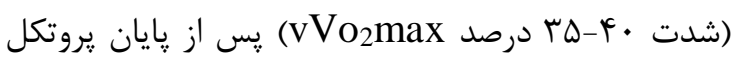

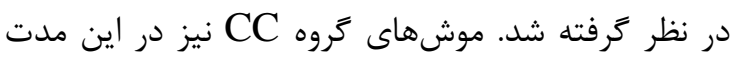
مورد كاواز كوركومين (ساخت سيخما آمريكا) قرار كرفتند. موشهاى كروه EC نيز در اين مدت تحت هر دو دو مداخله

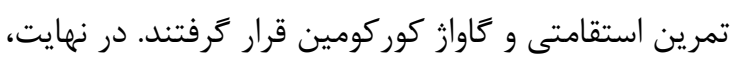
موشهاى تروه C، در طول مطالعه تحت هيج گُونه برنامه

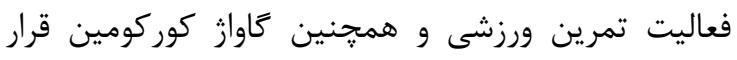

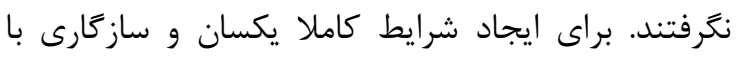

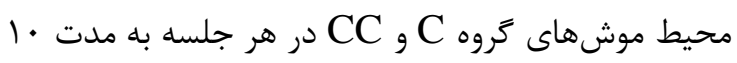

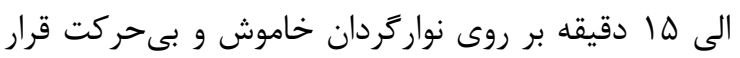

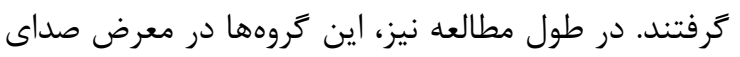

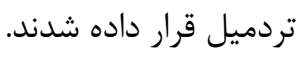




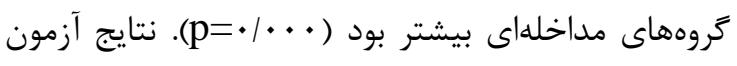
تحليل واريانس، وجود اختلاف معنى دار در بيان يروتئين

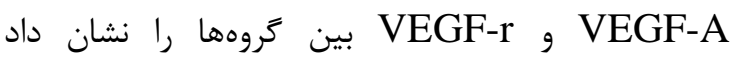
$(\mathrm{p}=\cdot / \cdot \cdot)$

جدول ا: ميانَّين وزن اوليه و نهايى موشها (كرم)

\begin{tabular}{|c|c|c|}
\hline وزن نهايى (كرم) & $\begin{array}{c}\text { وزن اوليه } \\
\text { (كرم) }\end{array}$ & كروهها \\
\hline $19 / r \pm 9 r / 9 \Lambda$ & $\mid \psi / \cdot \pm \lambda r / q r$ & كنترل \\
\hline $19 / r \pm q 9 / 9$. & $|F /| \pm q \cdot / r \Lambda$ & استقامتى \\
\hline $\mid V / r \pm q \varepsilon / F F$ & $\mid F / \cdot \pm \Delta F / V \Lambda$ & كنترل كور كومين \\
\hline$r \cdot / T \pm 1 \cdot / r V$ & $|r /| \pm V \psi / T q q$ & كوركومين \\
\hline
\end{tabular}

اعداد به شكل ميانكين土 خطاى معيار بيان شدهاند

همانطور كه در نمودار شماره ا نشان داده شده است

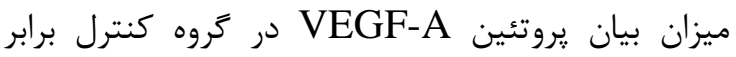

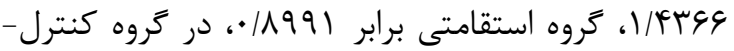

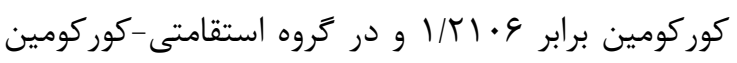

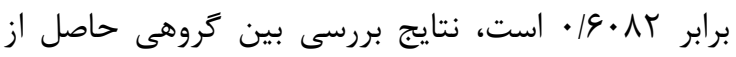

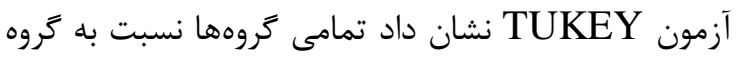

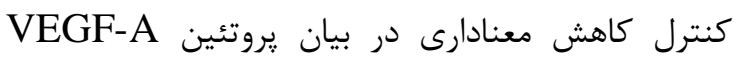

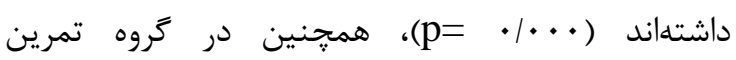
استقامتى-كوركومين كاهش معنادار در بيان يروتئين

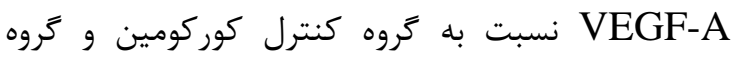

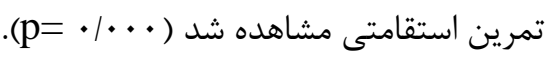

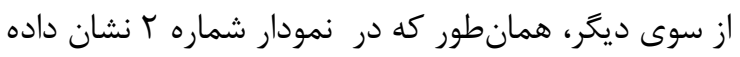

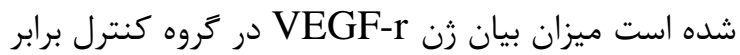

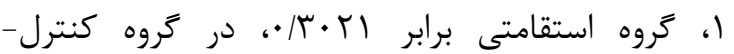

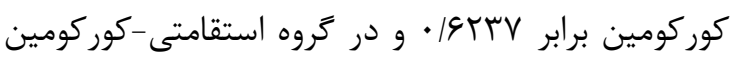

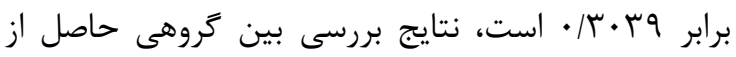

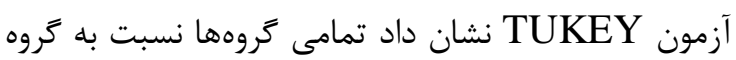

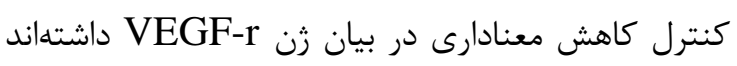

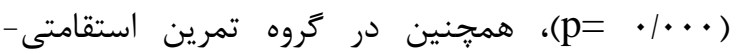

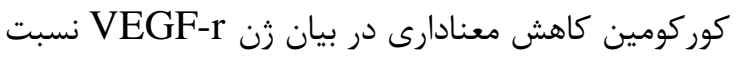

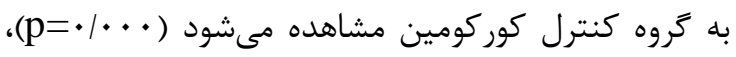

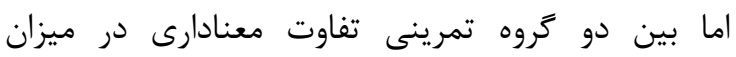

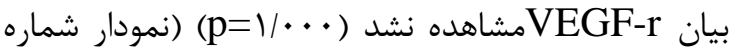

توليدى ampliqon (دانمارك) و ا ميكروليتر از يرايمرها Forward

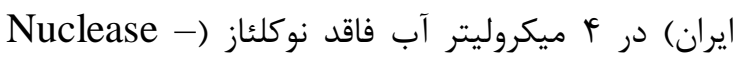
free Water براى رسيدن به حجم نهايى هابئ هاميكروليتر

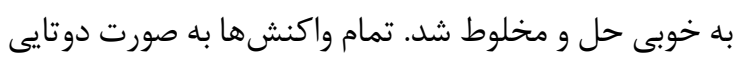

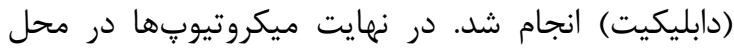

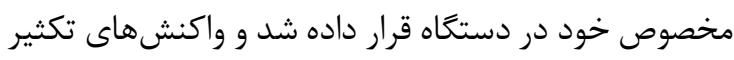

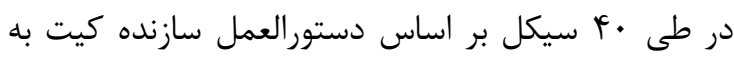
صورت زير انجام شد:

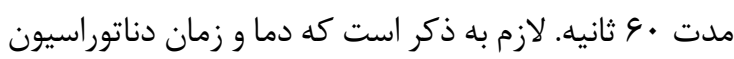

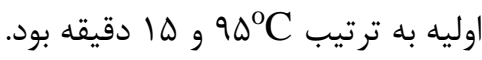

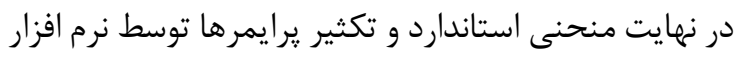

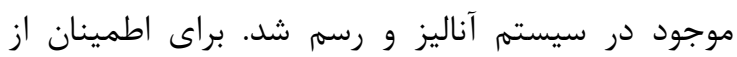

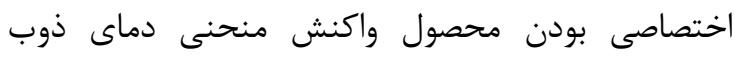

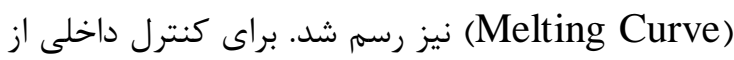
زن خانهدارى GAPDH استفاده شد و جهت كنترل كيف كئى

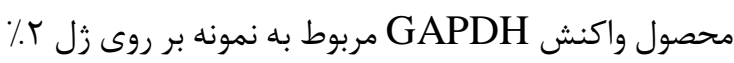

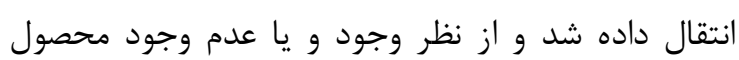

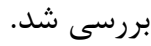
تجزيه و تحليل آمارى يافتهها: جهت آمار توصيفى

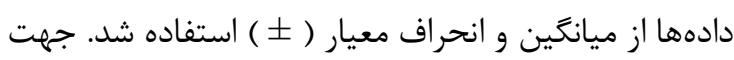
بررسى نرمال بودن دادهها از آزمون كولموكروف اسميار (

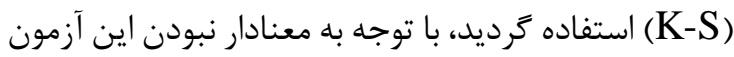

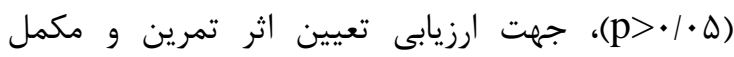
كور كومين از روش One Way ANOVA إستفاده شد.

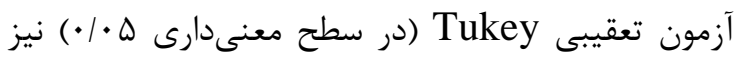

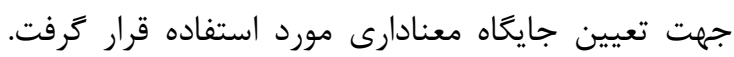

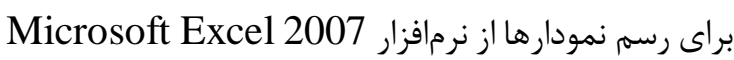

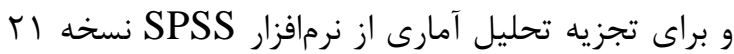

استفاده شد.

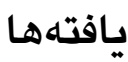

وزن موشهاى تمام گروههاى مورد يزوهش در جدول

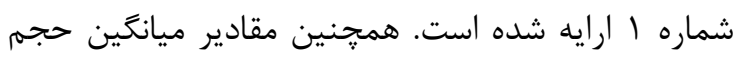

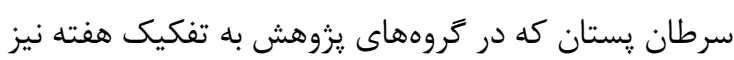

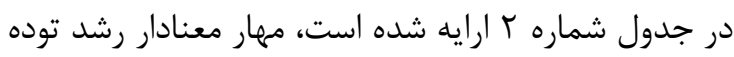

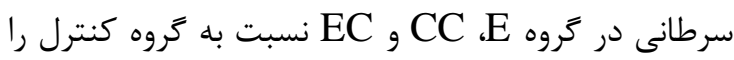

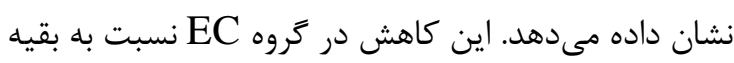




\begin{tabular}{|c|c|c|c|c|}
\hline استقامتى كوركومين & كنترل كور كومين & استقامتى & كنترل & هفته/Fروه \\
\hline$\Delta V / I r \pm I f$ & $\Delta F / / \Delta \pm V r$ & $\Delta \Delta / / \Delta \pm V \varepsilon$ & $F V /|q \pm F|$ & اول \\
\hline 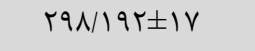 & $r r r / \Lambda I \pm \Delta r$ & $r F / / \Lambda \Lambda \pm r G$ & $\Delta ৭ \& / F Y Y \pm V Y$ & دوم \\
\hline$V \Psi \Delta / r \wedge r \pm \Delta r$ & $\Delta F \Delta / \Gamma r \Lambda \pm r$. & $q F q / F r 1 \pm r q$ & 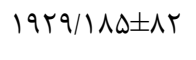 & سوم \\
\hline 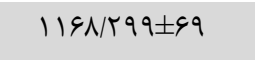 & $1199 / 9 \Delta \cdot \pm 9 \varsigma$ & $\mid V \vee \wedge / F q \Delta \pm \Lambda F$ & $r \varepsilon \mid 1 / r \cdots \pm \Delta f$ & جهارم \\
\hline IrVYF/RAVIrr & $19 \wedge 9 / \wedge \wedge \vee \pm \Delta \vee$ & $\mid V r r / \& q \cdot \pm I V$ & $\varepsilon \wedge \Delta Y / / F Y \pm \wedge \varepsilon$ & ينجم \\
\hline
\end{tabular}

اعداد به شكل ميانگين土 خطاى معيار بيان شدهاند

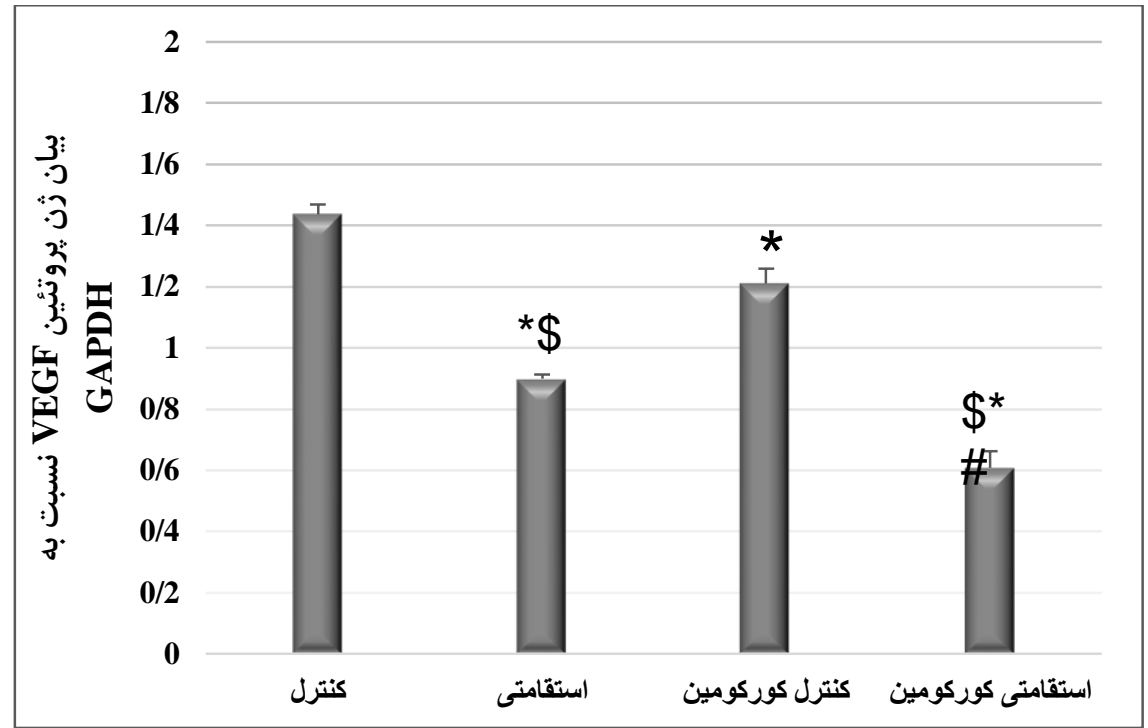

نمودار ا: تغييرات بيان بروتئين VEGF-A در تروههاى يزوهش

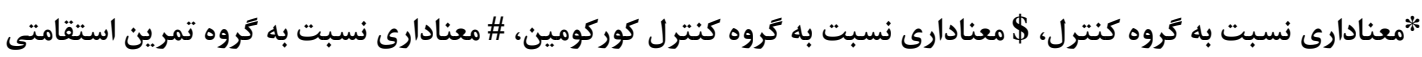

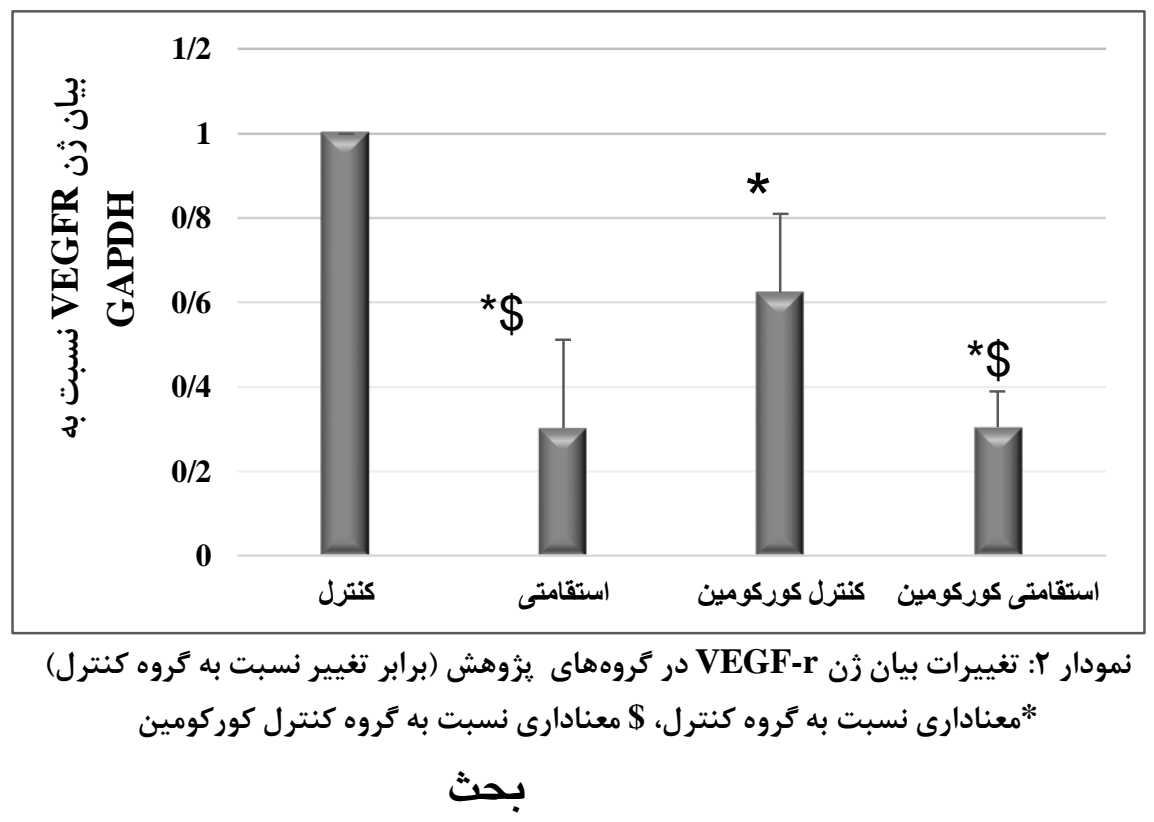




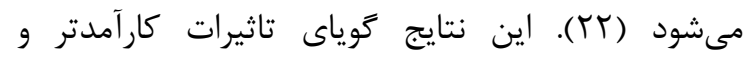
سودمندتر هر دو مداخله مذكور نسبت به هر مداخله به تنهايى است. از سوى ديخر، يزوهش حاضر نشان داد كه تمرين استقامتى، مكمل كوركومين و تركيبى از هر دو

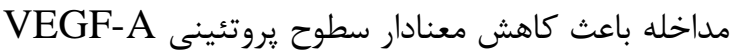
و بيان زن VEGF-r در توده سرطان يستان در مقايسه با معنا گروه كنترل مىشوند. همانند تاثير برآيندى تمرينكوركومين بر رشد توده سرطانى، تاثير برآيندى اين دو دون

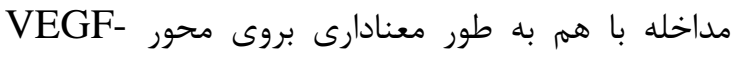
A/VEGF-r

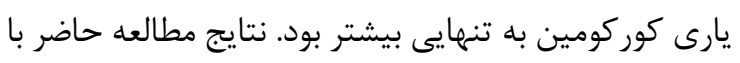

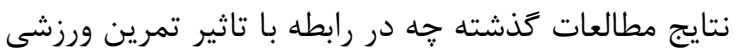

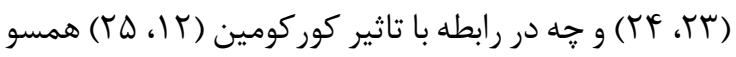
بود. اينكه تاثير برآيندى هر دو مداخله با هم بروى محور مذكور هنوز هم مطالعهايى صورت نكرفته است، تفسير نتايج

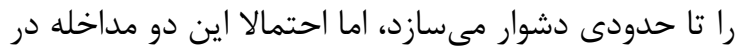
تركيب با هم اثر تحريكى بيشتر را در ريز محيط سرطان مانسان يستان فراهم مى آورد كه به مهار هر جه جه به بيشتر محور

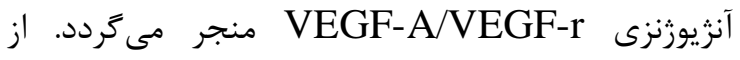
آنجايى كه، آنزيوزنز عامل اصلى و كليدزى در در رشد توده

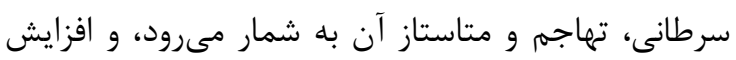
سطوح VEGF-r و لو لعاعث افزايش سطوح رَزايى در بافت سرطان مىشود و متعاقبا منجر به افزايش رشد و توسعه سلولهاى سرطانى مىشود (ه)، بر اين اساس و گ ₹EGGF هدف براى داروها و مداخلههاى ضد رگزايى در رشد توده

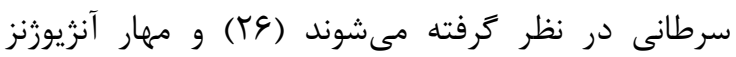
مىتواند يك روش درمانى بسيار مهرم در بيمارى سرطان

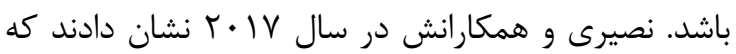
• 1 هفته تمرين استقامتى منجر به مهار رگزايى از طريق

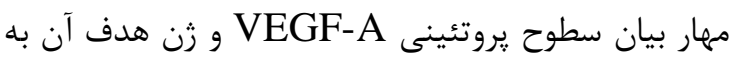
نام HGS در بافت سرطان يستان در موشهاى مهاى ماده مبتلا

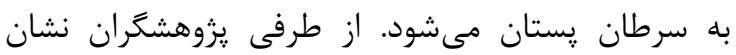

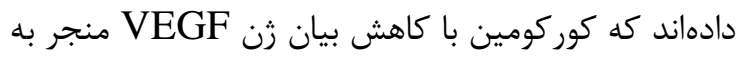
كاهش رگزايى و كاهش رشد توده سرطانى در بافت

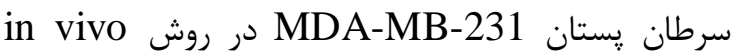
مىشود (T)). بنابراين به نظر مىرسد تاثير توامان تمرين

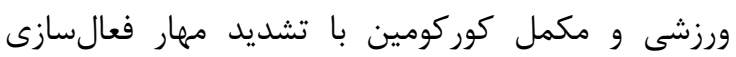

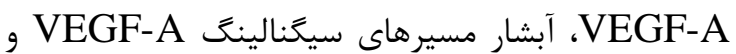

يزوهش حاضر به منظور بررسى تاثير برآيندى تمرين

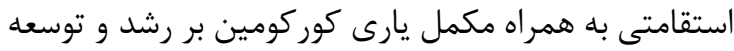

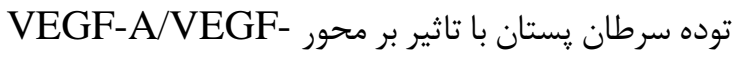

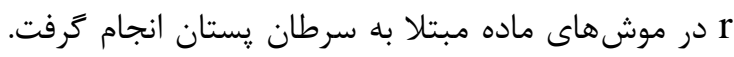

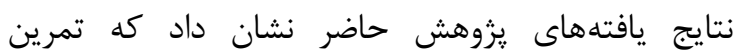
استقامتى، كوركومين و تركيبى از هر دو مداخله باعث كاهش رشد، توسعه توده سرطان يستان با كاهش معنادار

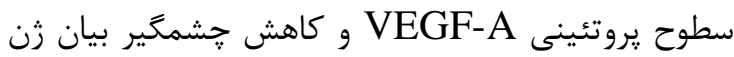
VEGF-r

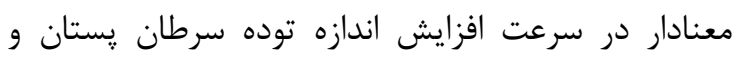
سطوح يروتئينى VEGF-A در زروه تمرين-كوركومين نسبت به گروه كوركومين و گروه تمرين استقامتى بود.

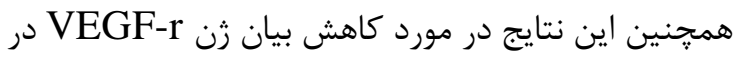

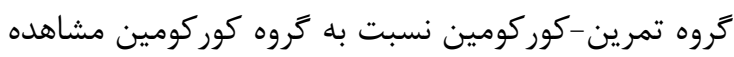
شد. نتايج مطالعه حاضر در رابطه با كاهش رشد توده سرطان در گروه تمرين استقامتى نه تنها با نتايج بسيارى از ماز رها

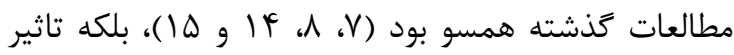
سودمند تمرين استقامتى بر كاهش روند توسعه و رشد سرطان كه در مطالعات كذشته اثبات شده است را تاييد مى كند. از طرفى نتايج مطالعه حاضر در رابطه با كاهش رشد و توسعه توده سرطان در گروه مكمل يارى كوركومين

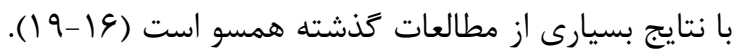
بر اين اساس، از مهممترين نتايج يثوهش حاضر تاثير فزاينده

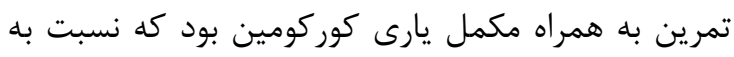

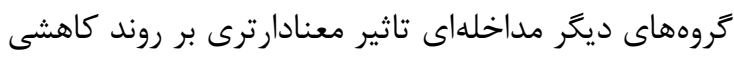

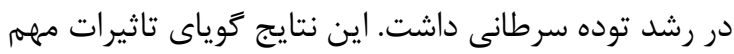

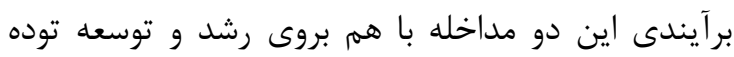

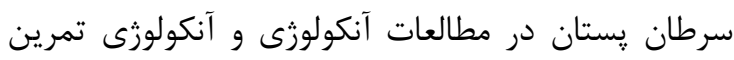
ورزشى است. هرجند در اين راستا تا كنون مطالعهايى انجام نَرفته است، اما مطالعات ديخر نشان داده اند كه كور كومين

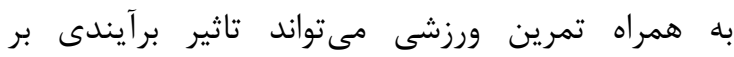

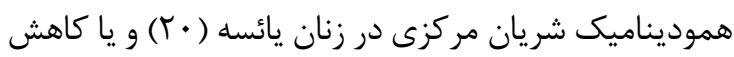
التهاب و بهبود عملكرد ناشى از آسيب عضلانى تمرين يناتين ورزشى برونكراى دويدن در سراشيبى و سربالايى در

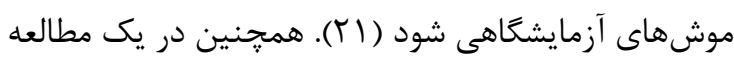
ديخر نشان داده شد كه ^ هفته تمرين استقامتى در تركيب با كوركومين باعث كاهش معنادار يروتئين شوك گرمايى HSP72 كروه نسبت به گروه كنترل و هر يك از دومداخله به تنهايى 
كور كومين احتمالا با تاثير بر مولكول هاى ييامدهى مههم در

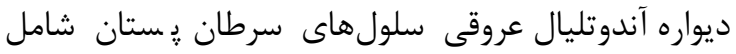
فEGF-r و VEGF-A

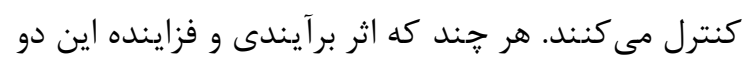

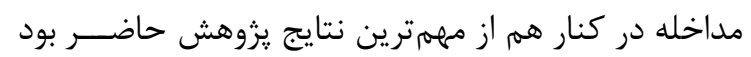

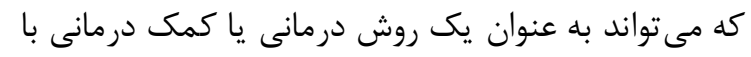

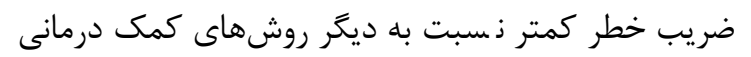

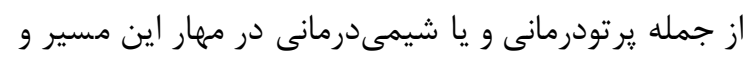

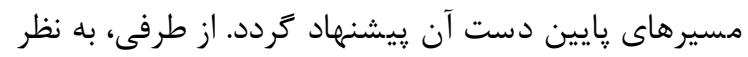

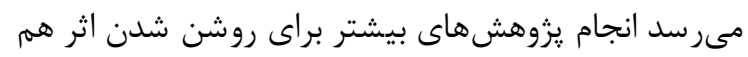

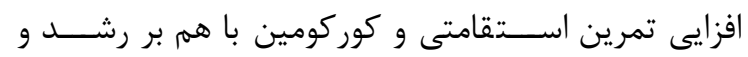
توسعه توده سرطان بِستان موضوع ضرورى است. از نقاط

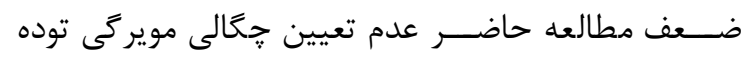

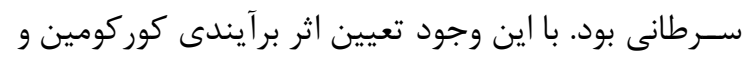

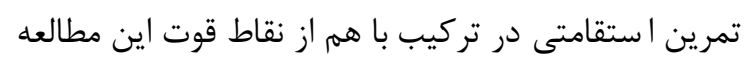
به شمار مىروند.

\section{تشكر و قدردانى}

از تمامى افرادى كه در بخش هاى مختلف در انجام اين

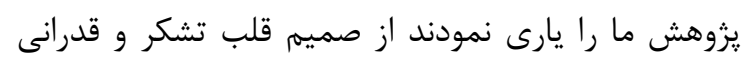

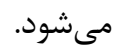

\section{تعارض منافع \\ نويسندًان اعلام مى دارند كه هيج تعارض مناف منافعى در

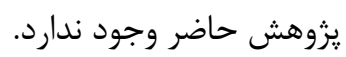

\section{References}

1. Bray F, Ferlay J, Soerjomataram I, Siegel RL, Torre LA, Jemal A. Global cancer statistics 2018: GLOBOCAN estimates of incidence and mortality worldwide for 36 cancers in 185 countries. CA: a cancer journal for clinicians. 2018; 68(6):394-424.

2. Zhang Q, Lu S, Li T, Yu L, Zhang Y, Zeng H, et al. ACE2 inhibits breast cancer angiogenesis via suppressing the VEGFa/VEGFR2/ERK pathway. Journal of Experimental \& Clinical Cancer Research. 2019; 38(1):1-12.

3. Shokri A, Pirouzpanah S, Foroutan-Ghaznavi M, Montazeri V, Fakhrjou A, Nozad-Charoudeh H, et al. Dietary protein sources and tumoral overexpression of RhoA, VEGF-A and VEGFR2
خوني ال كه منجر به تحريك افزايش شبكه عروق VEGF-r خونى در توده سرطان يستان مىشود مهار مى كند. به نظر

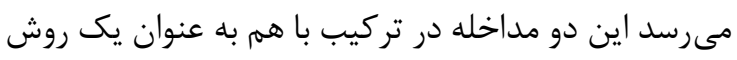

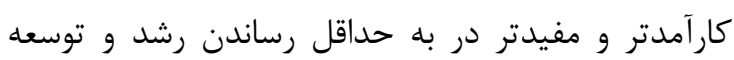
سرطان نسبت به هر كدام از مداخلهها به تنهايى به شمار

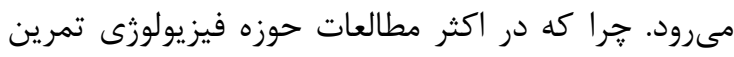

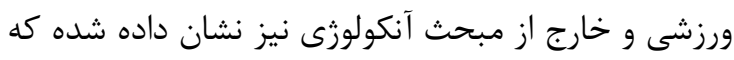
تمرين تمرين ورزشى در تركيب با مداخلههاى ديگر تاثير

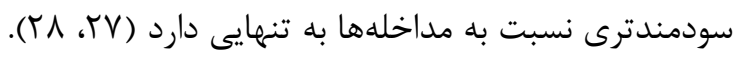

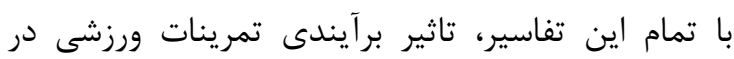

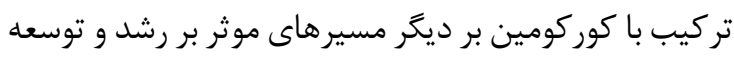
سرطان پستان از جمله مسيرهاى كليدى ديگر در آنزيوزنز مشخص نشده است. از اين رو نتيجه گيرى قطعى در اين مورد كه تمرين ورزشى استقامتى به همراه مكمل يارى كور كومين بر كليه مسيرهاى موثر درگير در آنزيوزنز و رشد سرطان تاثير مى گذارد، را دشوار كرده است.

\section{نتيجهكيرى}

با توجه به نتايج يزوهش حاضر، احتمالا تمرين استقامتى و

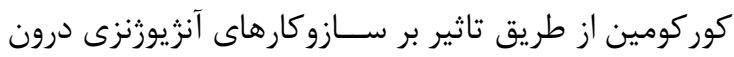
توده سرطان يستان از جمله محور VEGF-A/VEGF-r

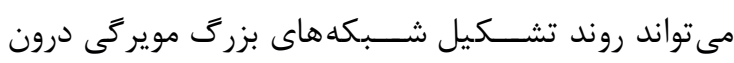

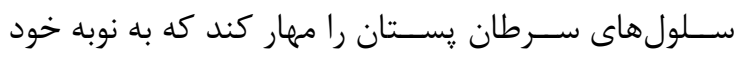

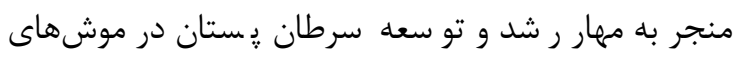

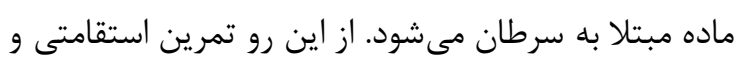

genes among breast cancer patients. Genes \& nutrition. 2019;14(1):22.

4. Banerjee S, Dowsett M, Ashworth A, Martin LA. Mechanisms of disease: angiogenesis and the management of breast cancer. Nature Clinical practice Oncology. 2007; 4(9):536-50.

5. Hanahan D, Weinberg RA. Hallmarks of cancer: the next generation. cell. 2011; 144(5): 646-74.

6. Himbert C, Delphan M, Scherer D, Bowers LW, Hursting S, Ulrich CM. Signals from the adipose microenvironment and the obesity-cancer link-a systematic review. Cancer Prevention Research. 2017; 10(9):494-506. 
7. Delphan M, Agha Alinejad H, Delfan M, Dehghan S. Intratumoral Effects of Continuous Endurance Training and High Intensity Interval Training on Genes Expression of miR-21 and bcl-2 in Breast Cancer Bearing Female mice. Iranian Quarterly Journal of Breast Disease. 2017; 10(2):49-57.

8. Betof AS, Lascola CD, Weitzel D, Landon C, Scarbrough PM, Devi GR, et al. Modulation of murine breast tumor vascularity, hypoxia and chemotherapeutic response by exercise. JNCI: Journal of the National Cancer Institute. 2015; 107(5).

9. Buss LA, Dachs GU. The Role of Exercise and Hyperlipidaemia in Breast Cancer Progression. Exercise immunology review. 2018; 24.

10. Nasiri M, Peeri M, Matinhomaei H. Endurance Training Attenuates Angiogenesis Following Breast Cancer by Regulation of MiR-126 and MiR-296 in Breast Cancer Bearing Mice. International Journal of Cancer Management. 2017; 10(6).

11. Song X, Zhang M, Dai E, Luo Y. Molecular targets of curcumin in breast cancer. Molecular medicine reports. 2019;19(1):23-9.

12. Chakraborty G, Jain S, Kale S, Raja R, Kumar S, Mishra R, et al. Curcumin suppresses breast tumor angiogenesis by abrogating osteopontininduced VEGF expression. Molecular medicine reports. 2008;1(5):641-6.

13. Jensen MM, Jorgensen JT, Binderup T, Kjaer A. Tumor volume in subcutaneous mouse xenografts measured by microCT is more accurate and reproducible than determined by 18F-FDG-microPET or external caliper. BMC medical imaging. 2008; 8(1):1-9.

14. Mirakhori Z, Kordi MR, Alizadeh S, Anoosheh L, Amani Shalamzari S, et al. The Effect of Aerobic Training on Plasma Estradiol and mir206 and ER $\alpha$ Expression in mice with Breast Cancer. Iranian Quarterly Journal of Breast Diseases. 2015;7(4):23-32.

15. Hagar A, Wang Z, Koyama S, Serrano JA, Melo L, Vargas S, et al. Endurance training slows breast tumor growth in mice by suppressing Treg cells recruitment to tumors. BMC cancer. 2019; 19(1):1-10.

16. Majumdar AP. Preclinical animal tumor models to study prevention of colon cancer recurrence by curcumin. Animal Models in Cancer Drug Discovery: Elsevier. 2019; 2:93-307.

17. You Z, Li B, Xu J, Chen L, Ye H. Curcumin suppress the growth of hepatocellular carcinoma via down-regulating SREBF1. Oncology Research Featuring Preclinical and Clinical Cancer Therapeutics. 2020.

18. Rutz J, Maxeiner S, Juengel E, Bernd A, Kippenberger S, Zöller N, et al. Growth and
Proliferation of Renal Cell Carcinoma Cells Is Blocked by Low Curcumin Concentrations Combined with Visible Light Irradiation. International journal of molecular sciences. 2019; 20(6):1464.

19. Coker-Gurkan A, Bulut D, Genc R, Arisan E-D, Obakan-Yerlikaya P, Palavan-Unsal N. Curcumin prevented human autocrine growth hormone $(\mathrm{GH})$ signaling mediated NF- $\mathrm{B}$ activation and miR-183-96-182 cluster stimulated epithelial mesenchymal transition in T47D breast cancer cells. Molecular biology reports. 2019;46(1):355-69.

20. Sugawara J, Akazawa N, Miyaki A, Choi Y, Tanabe Y, Imai T, et al. Effect of endurance exercise training and curcumin intake on central arterial hemodynamics in postmenopausal women: pilot study. American journal of hypertension. 2012;25(6):651-6.

21. Davis JM, Murphy EA, Carmichael MD, Zielinski MR, Groschwitz CM, Brown AS, et al. Curcumin effects on inflammation and performance recovery following eccentric exercise-induced muscle damage. American Journal of Physiology-Regulatory, Integrative and Comparative Physiology. 2007.

22. Memar Moghadam M. Effects of lead acetate, endurance training and curcumin supplementation on heat shock protein levels in liver tissue. Iranian Journal of Endocrinology and Metabolism. 2011;13(1):74-81.

23. Ahmadian M, Azizbeigi K, Delfan M, Atashak S. Effects of 10 week continuous endurance training on angiopoietin-1 gene expression and the tie2 protein in mice with breast cancer. Medical Journal of Tabriz University of Medical Sciences and Health Services. 2019; 41(1): 7-13.

24. Ahmadian M, Azizbeigi K, Delphan M, Atashak S. The Effect of High Intensity Interval Training on STAT-3 and Angiopoietin-1 Gene Expression, and tie-2 Protein in Mice with Breast Cancer. Iranian Quarterly Journal of Breast Disease. 2018;11(1):37-46.

25. Fu Z, Chen X, Guan S, Yan Y, Lin H, Hua Z-C. Curcumin inhibits angiogenesis and improves defective hematopoiesis induced by tumorderived VEGF in tumor model through modulating VEGF-VEGFR2 signaling pathway. Oncotarget. 2015; 6(23):19469.

26. Abdolmaleki Z, Arab H-A, Amanpour S, Muhammadnejad S. Anti-angiogenic effects of ethanolic extract of Artemisia sieberi compared to its active substance, artemisinin. Revista Brasileira de Farmacognosia. 2016; 26(3):32633.

27. Delphan M, Rashidlamir A, Delphan F. Resting plasma AgRP levels response to exerciseconjugated diet and only diet in overweight and 
obese sedentary females. Biology of Sport. 2012; 29(1).

28. Delphan M, Rashidlamir A, Delfan F, Izadpanah N, Rahbarizade F. The effects of two weight loss protocol onresting plasma concentration of IL-6 inoverweight and obese health sedentary female of college students. 22nd International Congress on Pediatrics. 2010. 